\title{
A INDISPONIBILIDADE DO INTERESSE PÚBLICO: CONTEÚDO, NATUREZA JURÍDICA, FUNDAMENTOS NORMATIVOS E IMPACTOS NO DIREITO ADMINISTRATIVO BRASILEIRO
}

\author{
THE UNAVAILABILITY OF PUBLIC INTEREST: \\ CONTENT, LEGAL NATURE, NORMATIVE FOUNDATION \\ AND IMPACTS ON BRAZILIAN ADMINISTRATIVE LAW
}

LUZARDO FARIA ${ }^{1}$

\section{RESUMO}

O objetivo do presente artigo é realizar uma análise verticalizada do princípio da indisponibilidade do interesse público. Para tanto, inicialmente será explorado o conteúdo jurídico desse princípio, a fim de identificar do que trata a indisponibilidade do interesse público. Na sequência, será examinada a natureza jurídica da indisponibilidade (isto é, se ela de fato se constitui como um princípio ou se deve ser encarada como uma regra). Diante das críticas quanto à suposta ausência de amparo a este princípio no Direito brasileiro, demonstra-se os seus fundamentos normativos em nível constitucional e infraconstitucional. Ao final, por se tratar de uma das normas-chave do regime jurídico-administrativo, analisa-se os principais impactos da indisponibilidade do interesse público para o Direito Administrativo brasileiro. 0 artigo utiliza-se de pesquisa bibliográfica nacional e estrangeira, amparado no método hipotético-dedutivo.

PALAVRAS-CHAVE: Interesse público. Indisponibilidade. Conteúdo jurídico. Natureza jurídica. Fundamentos normativos.

\section{ABSTRACT}

The purpose of this article is to conduct a vertical analysis of the principle of unavailability of the public interest. Therefore, it starts analyzing the legal content of this principle, in order to identify what it really means. In the sequence, the legal nature of the unavailability will be examined (that is, if it is in fact constituted as a principle or if it should be seen as a rule). Once there is a relevant criticism regarding the alleged lack of support for this principle in Brazilian law, the article demonstrates its normative foundations at the constitutional and infraconstitutional level. In the end, considering that this is one of the key norms of the

\footnotetext{
1 Mestre e Bacharel em Direito do Estado pela Universidade Federal do Paraná. Professor do Curso de Especialização em Direito Administrativo do Instituto de Direito Romeu Felipe Bacellar. Editor-Adjunto da Revista de Investigações Constitucionais. Diretor Administrativo-Adjunto do Instituto de Direito Administrativo Sancionador Brasileiro. Membro do Instituto Paranaense de Direito Administrativo. Advogado. ORCID: http://orcid.org/0000-0001-7330-2649. farialuzardo@hotmail.com
} 
legal-administrative regime, the main impacts of the unavailability of the public interest for Brazilian Administrative Law are analyzed. The article uses national and foreign bibliographic research, supported by the hypothetical-deductive method.

KEYWORDS: Public interest. unavaliability. Legal content. Legal nature. Normative foundation.

\section{INTRODUÇÃO}

O princípio da indisponibilidade do interesse público é tido, ao lado na noção de supremacia do interesse público, como uma das normas fundamentais e estruturantes de todo o regime jurídico-administrativo. Segundo Celso Antônio Bandeira de Mello, isso ocorre não tanto por possuírem, por si próprios, virtudes que os imponham como tal, mas porque é possível constatar que o Direito Administrativo como um todo encampou esses princípios como seu norte jurídico e, a partir disso, validou-se como "fonte-matriz do sistema" (MELLO, 2015, p. 57). Afinal, é facilmente perceptível que as duas normas - que refletem, em solo brasileiro, o clássico binômio de prerrogativas e sujeições que contorna o Direito Administrativo por todo o mundo - é o que dá uma consistência lógica uniforme ao regime jurídico-administrativo.

No entanto, apesar de, ao menos em tese, ser relegada imensa importância ao princípio da indisponibilidade, na prática muito pouco se escreveu sobre ele, restando ainda como um tema praticamente intocado pela ciência do Direito Administrativo no Brasil.

Nesse sentido, Mariana de Siqueira constata que no estudo da categoria de interesse público pelo Direito Administrativo brasileiro "preponderam os trabalhos destinados a repensar a supremacia do interesse público sobre o privado, sendo demasiado escassos aqueles destinados a refletir especificamente sobre a indisponibilidade do interesse público". A indisponibilidade, reforça a autora, "costuma aparecer nas obras sobre a supremacia a título de 'carona' nas arguições teóricas ali construídas, não como objeto principal a constar do título, mas sim como elemento teórico analisado internamente ao longo dos escritos, de maneira pontual e a título acessório" (SIQUEIRA, 2016, p. 202). Há até mesmo que sustente que a indisponibilidade é uma mera decorrência do princípio da supremacia. ${ }^{2}$

Essa circunstância acaba, frequentemente, por gerar aplicações equivocadas do referido princípio. Em qualquer caso, saber qual é o real conteúdo jurídico de um determinado princípio do qual se pretende fazer uso, conhecer as normas do sistema que respaldam sua existência e os elementos que o compõe são etapas primordiais e inescusáveis para a sua adequada interpretação e aplicação nos casos concretos. A ausência do conhecimento desses fatores pela doutrina e pelos operadores do direito, então, é o problema que justifica a presente pesquisa.

Essas constatações - é importante que fique claro - não se aplicam apenas ao princípio da indisponibilidade do interesse público. No entanto, é no mínimo curioso que a doutrina,

2 Nesse sentido é o posicionamento de MEIRELLES, Hely Lopes. Direito Administrativo Brasileiro. 38. ed. São Paulo: Malheiros, 2012. p. 108; e de MARTINS JÚNIOR, Wallace Paiva. Princípio do interesse público. In: DI PIETRO, Maria Sylvia Zanella; 
a despeito do reconhecimento honroso com que menciona o princípio da indisponibilidade, não tenha até o momento se dedicado de modo aprofundado a identificar cada uma dessas peculiaridades em seu regime jurídico.

Ao relegar ao princípio da indisponibilidade um tom quase que de "obviedade", a comunidade acadêmica abriu espaço para que pouco ou quase nada se conhecesse a respeito desse princípio. E, em última análise, autorizou a Administração Pública e o Poder Judiciário a lançarem mão da noção de indisponibilidade do interesse público como um conceito chavão que serve de amarra à Administração quando eles quiserem.

Buscando combater esse cenário, o objetivo do presente artigo é realizar uma análise verticalizada do princípio da indisponibilidade do interesse público. Para tanto, inicialmente será explorado o conteúdo jurídico desse princípio, a fim de identificar do que trata a indisponibilidade do interesse público. Na sequência, será examinada a natureza jurídica da indisponibilidade (isto é, se ela de fato se constitui como um princípio ou se deve ser encarada como uma regra). Diante das críticas quanto à suposta ausência de amparo a este princípio no Direito brasileiro, demonstra-se os seus fundamentos normativos em nível constitucional e infraconstitucional. Ao final, por se tratar de uma das normas-chave do regime jurídico-administrativo, analisa-se os principais impactos da indisponibilidade do interesse público para o Direito Administrativo brasileiro. 0 artigo utiliza-se de pesquisa bibliográfica nacional e estrangeira, amparado no método hipotético-dedutivo.

\section{O CONTEÚDO JURÍDICO DA INDISPONIBILIDADE DO INTERESSE PÚBLICO}

Assim como ocorreu com o princípio da supremacia e com a própria noção de interesse público, o reconhecimento quase que honorífico do princípio da indisponibilidade no Direito Administrativo brasileiro concretiza-se principalmente a partir da difusão dos ensinamentos de Celso Antônio Bandeira de Mello. Uma vez que o autor elege esses conceitos como a base estrutural de todo o regime jurídico-administrativo no Brasil e que sua obra foi, sem sombra de dúvidas, a que mais impactou a academia e a jurisprudência em matéria de Direito Administrativo nas últimas décadas, não haveria como o princípio da indisponibilidade não receber tamanha importância.

Como marco inicial para a análise do conteúdo jurídico da indisponibilidade do interesse público, portanto, toma-se emprestada a lição de Bandeira de Mello. Segundo o administrativista, o significado da indisponibilidade reside no fato de que "sendo interesses qualificados como próprios da coletividade - internos ao setor público -, eles não se encontram à livre disposição de quem quer que seja, por inapropriáveis." De acordo com ele, "o próprio órgão administrativo que os representa não tem disponibilidade sobre eles, no sentido de que lhe incumbe apenas curá-los - o que também é um dever - na estrita conformidade do que predispuser a intentio legis" (MELLO, 2015, p. 76).

Apesar da profusão da definição de Celso Antônio e da influência que teve na obra de diversos outros autores que se enveredaram pelo tema, o fato é que não existe um consenso 
na doutrina brasileira a respeito do conteúdo do princípio da indisponibilidade do interesse público - e isso talvez exatamente por conta de que os escritos sobre o tema via de regra nunca o enfrentaram com a especificidade necessária para compreendê-lo adequadamente.

Em preciosa pesquisa, Natalia Pasquini Moretti (2012, p. 460) identifica que a indisponibilidade é tratada a partir de pelo menos quatro facetas pela doutrina nacional: (i) indisponibilidade da finalidade legal; (ii) indisponibilidade do dever de agir; (iii) indisponibilidade de bens e serviços públicos; (iv) indisponibilidade das competências administrativas.

(i) A indisponibilidade da finalidade legal é a faceta à qual o princípio em questão é mais comumente relacionado. Como visto, desde as lições clássicas dos autores mais tradicionais que foram elencados acima entende-se que na atividade administrativa pública "o bem não se entende vinculado à vontade ou personalidade do administrador, porém à finalidade impessoal a que essa vontade deve servir" (LIMA, 2007, p. 37), a qual é encontrada exatamente na legislação.

Por essa perspectiva, à Administração Pública é vedada a tomada de qualquer decisão que não destinada à satisfação dos objetivos impostos ao Estado pela legislação. Isto é, a Administração não pode se desvencilhar dos comandos e direcionamentos que lhe foram impostos pela Constituição e pelas normas infraconstitucionais. Afinal, o interesse público, em termos jurídicos, é aquilo definido pelo legislador como tal.

É interessante observar que nem mesmo em casos de conflitos de interesses públicos a Administração poderá dispor da finalidade legal. Em um primeiro momento, isso poderia parecer impossível nos casos em que duas normas com finalidades opostas se chocam em um determinado caso concreto. No entanto, deve-se lembrar que a finalidade máxima protegida pela indisponibilidade do interesse público é aquela das normas constitucionais, interpretadas e aplicadas sistematicamente, como um corpo homogêneo de diretrizes a serem seguidas pela Administração Pública. Assim, quando, diante de uma situação específica, a Administração se vir obrigada a deixar de concretizar a finalidade pretendida por determinada norma legal, é imprescindível que isso seja feito apenas na medida em que for adequado, necessário e proporcional. Assim se estará garantindo a realização do interesse público em uma visão mais ampla.

(ii) A indisponibilidade do dever de agir é o que faz com que a Administração Pública deva estar incessantemente empreendendo todos os seus esforços em prol da concretização do interesse público. Não pode o Estado deliberadamente deixar de agir quando enxerga, no caso concreto, a presença de um interesse público, ${ }^{3}$ ainda que não exista disposição normativa específica exigindo aquela conduta concreta da Administração. Se isso ocorrer, são cabíveis medidas judiciais de caráter mandamental, impondo à Administração uma obrigação de fazer destinada à satisfação do interesse público. É a partir dessa noção que se desenvolve, por exemplo, o princípio da continuidade dos serviços públicos.

É importante ressaltar que a indisponibilidade do dever de agir também deve ser encarada por um prisma inverso, em relação aos deveres de omissão da Administração Pública. Nessas situações, esse mandamento possui a finalidade de impedir o Estado de tomar deter-

3 Nesse sentido, Edmir Netto de Araújo ressalta que "a atividade administrativa é compulsória para a Administração e exigível pelo administrado, se o exercício da competência é obrigatório, pois do interesse público o agente não pode dispor ao seu alvedrio, mas cumprir seu dever, usando do poder que a lei lhe atribuiu." ARAÚJO, Edmir Netto de. Curso de Direito Administrativo. 5. ed. São Paulo: Saraiva, 2010. p. 74-76. 
minada atitude quando se vislumbrar que esse ato importará na violação a um interesse público. ${ }^{4}$ Assim, exige-se que o Estado adote uma posição omissiva. É o que ocorre quando se demanda da Administração o respeito à função de defesa dos direitos fundamentais, a qual assegura aos particulares um espaço de liberdade preservado da ingerência estatal arbitrária.

(iii) A indisponibilidade de bens e serviços públicos relaciona-se com a ideia de que o administrador, por não ser proprietário da coisa pública, não pode dela dispor, senão nas estritas hipóteses previstas na legislação e desde que seguindo os procedimentos lá estabelecidos. ${ }^{5}$ É a lógica que impede a Administração Pública, por exemplo, de vender livremente seus imóveis ou de relegar à iniciativa privada a prestação de um determinado serviço público sem prévio processo licitatório.

(iv) A indisponibilidade das competências administrativas, por sua vez, é o que impede a Administração Pública de deixar cumprir com os deveres que Ihe são impostos pelo ordenamento e de utilizar-se das prerrogativas que o regime jurídico-administrativo a mune com o objetivo de instrumentalizar a persecução do interesse público. Segundo Maria Sylvia Zanella Di Pietro, "precisamente por não poder dispor dos interesses públicos cuja guarda lhes seja atribuída por lei, os poderes atribuídos à Administração têm o caráter de poder-dever; são poderes que ela não pode deixar de exercer, sob pena de responder por omissão". ${ }^{6}$

Está expressamente positivado no art. $2^{\circ}$, parágrafo único, II da Lei $n^{\circ} 9.784 / 99$, que prevê que a Administração Pública deverá observar os critérios de "atendimento a fins de interesse geral, vedada a renúncia total ou parcial de poderes ou competências, salvo autorização em lei". É o que fundamenta, por exemplo, as clássicas posições de que a Administração não pode dispor da aplicação das sanções administrativas ou do gozo das prerrogativas processuais conferidas à Fazenda Pública.

Seu conteúdo é bastante semelhante ao sentido atribuído à indisponibilidade do dever de agir, com a única diferença que quando se refere à indisponibilidade das competências administrativas existe alguma previsão normativa (constitucional, legal ou mesmo administrativa) imbuindo à Administração de uma prerrogativa a ser utilizada em hipóteses objetivamente descritas pela legislação para a persecução do interesse público. No primeiro caso, a indisponibilidade atua de modo mais genérico - isto é, ainda que não haja previsão de competência específica -, como forma de direcionar a atividade praeter legem da Administração à realização do interesse público.

Ao todo, trata-se de divisão meramente didática, que cumpre sua função ao sistematizar os diversos âmbitos de incidência do princípio da indisponibilidade do interesse público no Direito Administrativo brasileiro. O problema, porém, reside no fato de que frequentemente, diante de situações concretas, administradores públicos tomam suas decisões movidos por

4 Como lembra Luis de la Morena y de la Morena, "en ausencia de ese interés público, la Administración no podría actuar por cese o desaparición de su único (pero suficiente) soporte justificativo". MORENA, Luis de la Morena y de la. Derecho Administrativo e interés público: correlaciones básicas. Revista de Administración Pública, Madrid, n. 100-102, p. 847-880, ene./ dic. 1983. p. 847.

5 É a definição sobre o princípio da indisponibilidade que se extrai da doutrina de Diógenes Gasparini, desde as edições iniciais de seu Curso. Para ele, "não se acham, segundo esse princípio, os bens, interesses e serviços públicos à livre disposição dos órgãos da Administração Pública, a quem cabe curá-los, ou do administrador, que os representa". GASPARINI, Diógenes. Direito Administrativo. São Paulo: Saraiva, 1989. p. 10.

6 É a posição histórica ostentada pela autora, desde as edições iniciais de sua obra: DI PIETRO, Maria Sylvia Zanella. Direito Administrativo. 2. ed. São Paulo: Atlas, 1991. p. 67. 
apenas uma dessas facetas mencionadas acima, esquecendo, intencionalmente ou não, dos outros ângulos desse princípio.

E, ao fazerem isso, desvirtuam o real conceito da indisponibilidade do interesse público, dando azo a posições conservadoras e intransigentes, que na prática não são capazes de tutelar o interesse público de maneira verdadeiramente adequada. Afinal, uma vez que o interesse público é uma categoria de conteúdo mutável (de acordo não apenas com a legislação, mas até mesmo com o contexto fático de cada caso concreto), visões estanques do princípio da indisponibilidade jamais serão capazes de corresponder à complexidade dessa noção.

É o que acontece, por exemplo, quando autoridades públicas, pretensamente em nome da indisponibilidade do interesse público, se veem obrigadas a contestar ações ou de recorrer de decisões judiciais que Ihe sejam desfavoráveis, ainda que se identifique que o postulante, de acordo com as normas vigentes e com o entendimento jurisprudencial dominante, está com a razão. Nesse caso, utiliza-se da indisponibilidade das competências administrativas, sem se preocupar devidamente com a indisponibilidade das finalidades legais, uma vez que claramente não é para isso que o ordenamento jurídico fornece à Fazenda Pública instrumentos de defesa processual.

Assim, uma adequada compreensão do conteúdo jurídico do princípio da indisponibilidade do interesse público deve levar em consideração todas as múltiplas consequências que envolvem o âmbito de proteção dessa norma.

Além disso, é essencial ressaltar a função de "contra-peso" exercida pela indisponibilidade em relação à supremacia do interesse público, como forma de condicionar o agir administrativo no caminho da perseguição de uma determinada finalidade pública, não permitindo que as prerrogativas administrativas sejam utilizadas para qualquer outro fim que não o de interesse público. Nesse ponto se constata que os princípios da supremacia e da indisponibilidade do interesse público são, no Direito Administrativo brasileiro, condensações do que a doutrina administrativista tradicionalmente coloca como sendo a oposição entre, respectivamente, as prerrogativas e as sujeições da Administração Púbica (MELLO, 2015, p. 57), característica mais marcante desse ramo do Direito.

Dessa forma, a relação de complementariedade entre os princípios da supremacia e da indisponibilidade do interesse público mostra-se patente. Enquanto que o primeiro mune a Administração de prerrogativas tidas como necessárias para que o Poder Público possa realizar as complexas atividades que são de sua incumbência, o segundo atua como uma limitação a essas mesmas prerrogativas, condicionando a atividade administrativa ao atingimento das finalidades legais, o que faz através da imposição de uma série de sujeições que, assim como ocorre com as prerrogativas, também não são vistas nas relações privadas (HACHEM, 2011, p. 106).

E é exatamente o princípio da indisponibilidade que possibilita esse segundo ângulo de se encarar a função do interesse público no Direito Administrativo, fazendo com que "o bem comum seja, ao mesmo tempo, um fundamento e um limite para a atuação estatal" (HAEBERLIN, 2017, p. 65).

A indisponibilidade, portanto, muito mais do que simplesmente dizer o óbvio (como criticam alguns autores), possui importante função de direcionamento da atividade jurídico-administrativa. Deve-se compreender que é a indisponibilidade do interesse público a 
reposta, existente no próprio regime jurídico-administrativo, para frear os excessos indesejáveis que a Administração poderia vir a cometer caso lhe fossem outorgadas apenas prerrogativas (ESCOLA, 1989, p. 13). Afinal, esse princípio, "ao acentuar o dever estatal de servir aos anseios da coletividade, objetivou imprimir uma roupagem democrática ao Direito Administrativo pátrio," (HACHEM, 2011, p. 29) servindo como baliza jurídica do caminho que a Administração Pública, sob a égide da Constituição Federal de 1988, deve perseguir, a fim de alcançar a concretização dos objetivos delineados pela Lei Maior.

\section{A NATUREZA JURÍDICA DA INDISPONIBILIDADE DO INTERESSE PÚBLICO: PRINCÍPIO OU REGRA?}

Explanados os fatores que compõem o conceito jurídico do princípio da indisponibilidade do interesse público, cumpre agora analisar qual a natureza da referida norma para o Direito. Isto é, qual a forma através da qual ela se apresenta no ordenamento jurídico brasileiro. Afinal, isso também impacta fortemente no modo como ela será aplicada na prática pelos operadores do Direito.

O termo "princípio" é um dos mais polissêmicos de toda a ciência jurídica. ${ }^{7}$ Dois desses sentidos, porém, são utilizados com muito maior frequência para designar determinada norma jurídica como um princípio e, por tal razão, merecem maior atenção. São os sentidos extraíveis das teorias que classificam uma norma como princípio em razão da função exercida por ela no ordenamento jurídico e da forma de sua aplicação.

A primeira compreensão, tida como a mais tradicional, ${ }^{8}$ consideram os princípios as normas fundamentais do sistema, aquelas que conferem racionalidade a todo o sistema jurídica, aquela nas quais todo o ordenamento jurídico se estrutura e baseia. ${ }^{9}$

Celso Antônio Bandeira de Mello, principal desenvolvedor, como visto, da tese de que a supremacia e a indisponibilidade do interesse público ostentam caráter de verdadeiros princípios jurídicos, segue essa linha. Na definição do administrativa, os princípios represen-

7 Apenas para se ter noção da diversidade de sentidos que se atribui à expressão "princípios jurídicos", vale registrar que Ana Paula de Barcellos, em obra específica sobre a eficácia jurídica dos princípios constitucionais, identificou a existência de pelo menos sete diferentes compreensões para esse termo. Tamanha discordância decorre da diferença dos critérios utilizados pelos autores para classificarem determinada norma jurídica como um princípio. E apenas na pesquisa de Barcellos foram identificados os seguintes critérios: (i) o conteúdo da norma; (ii) a origem e a validade da norma; (iii) o compromisso histórico envolvido em torno da norma; (iv) a função exercida pela norma no ordenamento; (v) a estrutura linguística da norma; (vi) o esforço interpretativo exigido para compreensão do alcance e aplicação da norma; (vii) a forma de aplicação da norma. BARCELLOS, Ana Paula de. A eficácia jurídica dos princípios constitucionais: o princípio da dignidade da pessoa humana. 3. ed. rev. e atual. Rio de Janeiro: Renovar, 2011. p. 53-56.

8 A constatação é feita por Virgílio Afonso da Silva em: SILVA, Virgílio Afonso da. Princípios e regras: mitos e equívocos acerca de uma distinção. Revista Latino-Americana de Estudos Constitucionais, Belo Horizonte, n. 1, p. 607-630, jan./jun. 2003. p. 612. É importante registrar que, para além dos autores aqui citados, vários outros doutrinadores afiliam-se a essa corrente, como, por exemplo, José Joaquim Gomes Canotilho e Vital Moreira (CANOTILHO, J. J. Gomes; MOREIRA, Vital. Fundamentos da constituição. Coimbra: Coimbra Editora, 1991. p. 49), Cármen Lúcia Antunes Rocha (ROCHA, Cármen Lúcia Antunes. Princípios constitucionais da Administração Pública. Belo Horizonte: Del Rey, 1994. p. 23-25), José Afonso da Silva (SILVA, José Afonso da. Curso de Direito Constitucional Positivo. 32. ed. São Paulo: Malheiros, 2009. p. 91), entre outros. Daí a razão por esse ser considerado o modelo "tradicional" no Direito brasileiro.

9 Geraldo Ataliba, por exemplo, um dos nomes mais consagrados do Direito Tributário brasileiro na segunda metade do século XX, manifesta-se no seguinte sentido: "os princípios são a chave e essência de todo o direito. Não há direito sem princípios. As simples regras jurídicas de nada valem se não estiverem apoiadas em princípios sólidos". ATALIBA, Geraldo. Mudança da Constituição. Revista de Direito Público, São Paulo, n. 86, p. 181 - 186, abr./jun. 1988. p. 181. 
tam os mandamentos nucleares do sistema jurídico. Em passagem que se tornou bastante conhecida, o autor se refere aos princípios jurídicos como uma "disposição fundamental que se irradia sobre diferentes normas, compondo-lhes o espírito e servindo de critério para exata compreensão e inteligência delas, exatamente porque define a lógica e a racionalidade do sistema normativo, conferindo-Ihe a tônica que Ihe dá sentido harmônico". E, por essas razões, conclui que "violar um princípio é muito mais grave do que transgredir uma norma" (MELLO, 2015, p. 54).

O outro modelo bastante comum de diferenciar os princípios das regras jurídicas é a partir da sua forma de aplicação. Essa corrente, que ganhou grande atenção por parte da doutrina brasileira nas últimas décadas, é liderada pelas lições de Ronald Dworkin e Robert Alexy. É importante ressaltar que, apesar de quase sempre serem citados em conjunto, como se tratassem de uma mesma linha de pensamento, as teorias construídas por Dworkin e Alexy possuem alguns pontos de divergência entre si. ${ }^{10}$ No entanto, como dito, ambas adotam a estrutura lógico-normativa do comando jurídico em questão como critério para defini-lo como regra ou como princípio jurídico.

Para Dworkin, serão consideradas regras aquelas normas que se aplicam na lógica do "tudo-ou-nada". Isto é, uma vez prevista no ordenamento, se a norma for válida e forem preenchidos os requisitos para sua aplicação, ela incidirá inevitavelmente no caso concreto. Por outro lado, se ela for, por algum motivo, inválida (inconstitucional, por exemplo) ou se, no caso concreto, não tiverem sido preenchidos os requisitos necessários para sua incidência, ela não será aplicada. Não há gradação ou meio-termo. A regra se aplica ou não se aplica. Os princípios, por sua vez, seriam caracterizados por possuírem uma em sua estrutura uma dimensão de peso, que não permite a sua aplicação na lógica do "tudo-ou-nada". A aplicação de um determinado princípio, assim, deve levar em consideração a sua importância naquele caso concreto. Quanto mais importante for aquele princípio no caso concreto (em relação a outros que estiverem com ele colidindo), mais intensa será sua incidência (também em relação a esses outros princípios colidentes). Há, portanto, uma gradação inevitável, que só pode ser identificada conforme as peculiaridades de cada caso concreto (DWORKIN, 2010, p. 39-44).

A visão de Alexy, como dito, é bastante parecida com a de Dworkin, porém se distancia dela em algumas questões pontuais. Em relação às regras, a definição de Alexy praticamente coincide com a de Dworkin, afirmando que "as regras são normas que apenas podem ser cumpridas ou não. Se uma regra é válida, então deve fazer-se exatamente o que ela exige, nem mais nem menos". Uma das diferenças pontuais a que se referiu anteriormente é sentida na definição de princípios, os quais são tidos como "mandados de otimização", "normas que ordenam que algo seja realizado na maior medida do possível, dentro das possibilidades fáticas e jurídicas existentes no caso concreto". Diferentemente do que ocorre no caso de conflito de regras - quando se busca alguma cláusula de exceção ou se verifica a invalidade de uma delas e se aplica somente a outra -, na hipótese de colisão de princípios a solução será a restrição de um dos direitos fundamentais em prol do outro, sendo que essa restrição deverá ser adequada, necessária e proporcional para ser considerada válida (ALEXY, 2012, p. 64-71).

10 A esse respeito, remete-se novamente ao artigo de Virgílio Afonso da Silva, que traz uma análise aprofundada e detalhada sobre essas diferenças: SILVA, Virgílio Afonso da. Princípios e regras: mitos e equívocos acerca de uma distinção. Revista Latino-Americana de Estudos Constitucionais, Belo Horizonte, n. 1, p. 607-630, jan./jun. 2003. 
Dito isso, deve-se buscar compreender, agora, a partir de qual dessas duas principais formas o princípio da indisponibilidade se apresenta. Isto é, a indisponibilidade do interesse público é um princípio jurídico por conta do seu grau de fundamentalidade ou em razão de sua forma de aplicação? Ou atenderia a ambos os critérios?

Em relação ao seu grau de fundamentalidade não são cabíveis maiores discussões. Não apenas porque é esse o critério utilizado para embasar a noção de princípio jurídico pelo autor que pioneiramente desenvolveu a ideia de indisponibilidade do interesse público, mas também - e principalmente - porque: (i) é uma das normas que traz a fundamentação axiológica de todo o regime jurídico-administrativo, apontando, como diretiva geral, o caminho republicano e solidário que deve ser percorrido pela Administração Pública de acordo com a Constituição Federal de 1988; (ii) confere o respaldo constitucional exigido para legitimar juridicamente as sujeições a que é submetida a Administração Pública no Brasil; (iii) serve como cânone hermenêutico-interpretativo das demais normas do Direito Administrativo, imprimindo um tom de homogeneidade a todo esse sistema jurídico. ${ }^{11}$

A dúvida, porém, pode surgir quando se tenta verificar se a indisponibilidade do interesse público também poderia ser encaixada como um princípio jurídico nos termos de Robert Alexy e Ronald Dworkin. Ainda não foi feita pela doutrina qualquer análise nesse sentido em relação à indisponibilidade.

Do ponto de vista da natureza jurídica da norma, não se entende possível afirmar que a indisponibilidade do interesse público pode ser vista como um princípio, que pode ser aplicado em maior ou menor grau, a depender do caso concreto. Afinal, isso poderia levar à conclusão de que, dependendo das situações fáticas e jurídicas do caso concreto, a Administração Pública poderia estar mais ou menos vinculada à realização do interesse público. Admitir-se-ia, nesse sentido, que em alguns casos a Administração deliberadamente deixasse de atender ao interesse público.

Contudo, não é esse obviamente o conteúdo jurídico extraível do princípio da indisponibilidade, o que por dedução lógica inviabilizaria que sua forma jurídica fosse apresentada dessa maneira. Dessa maneira, a indisponibilidade do interesse público possui a estrutura lógico-normativa de regra no Direito Administrativo brasileiro.

Isso, contudo, não impede que interesses individuais ou coletivos stricto sensu possam ser perseguidos pela Administração, desde que estejam respaldados pelo ordenamento jurídico e desde que sua concretização corresponda, ainda que indiretamente, à satisfação do interesse público da coletividade em si mesmo considerada. A atividade de fomento estatal, já há muito consolidada na prática administrativa, apresenta-se como um bom exemplo disso, uma vez que, de modo geral, aceita-se sem contestações a sua validade em relação à indisponibilidade do interesse público.

Referida constatação se mostra relevante quando, por exemplo, examina-se acordos firmados pela Administração Pública com particulares tomando como base referencial o princípio da indisponibilidade do interesse público. Isso fica muito claro nos casos em que se discute a validade de acordos reconhecendo o direito dos indivíduos que estão litigando con-

11 Daniel Wunder Hachem também parte desses critérios para identificar a supremacia do interesse público como princípio jurídico no sentido de norma fundamental do sistema. Cf. HACHEM, Daniel Wunder. Princípio constitucional da supremacia do interesse público. Belo Horizonte: Fórum, 2011. p. 147. 
tra a Fazenda Pública na esfera judicial. A priori, o interesse da coletividade seria no sentido de que a advocacia pública envidasse todos os esforços necessários para que a entidade pública participante do conflito se sagrasse vencedora. Entretanto, em situações específicas o acordo com o particular litigante está autorizado. Mais uma vez: não somente para atender ao seu interesse individual, mas principalmente porque, em determinados casos (e serão apenas nesses casos que os acordos serão permitidos) não mais existirá o interesse coletivo de adversariedade da Fazenda Pública.

\section{OS FUNDAMENTOS NORMATIVOS QUE JUSTIFICAM A EXISTÊNCIA DO PRINCÍPIO DA INDISPONIBILIDADE DO INTERESSE PÚBLICO NO DIREITO ADMINISTRATIVO BRASILEIRO}

Uma vez expostos o que se entende pelo conteúdo e pela natureza jurídica do princípio da indisponibilidade do interesse público, deve-se agora demonstrar que a referida norma de fato existe no ordenamento jurídico, não se tratando de mera criação doutrinária. Afinal, é evidente que para que um determinado conceito ou valor seja aceita como norma jurídica ele deve possuir, explicita ou implicitamente, um fundamento identificável no ordenamento jurídico. ${ }^{12}$ Assim, deve-se buscar em que dispositivos jurídico-normativos do Direito brasileiro o princípio da indisponibilidade pode fundamentar sua existência enquanto norma jurídica.

Nesse sentido, é muito comum encontrar textos que, na tentativa de demonstrar o amparo constitucional do princípio da indisponibilidade do interesse público, apontam os dispositivos que impõem restrições aos administradores no tocante à venda de bens públicos, à realização de concurso público, à exigência de licitação, às reformas em patrimônio público, entre outros, como prova da existência jurídica desse princípio. No entanto, a metodologia empreendida parece estar equivocada por inverter os polos da equação: esses institutos não são a demonstração da existência do princípio da indisponibilidade, senão no máximo consequências dele (isso, se ele de fato for extraível da Constituição). Ou seja, ainda que a conclusão final a que se chegue seja a mesma, discorda-se do caminho percorrido por essa linha argumentativa.

Além disso, também se reconhece que muitos dos "subprincípios" decorrentes da indisponibilidade do interesse público foram constitucionalizados na Carta de 1988, a qual oferece um grande plexo de garantias aos cidadãos em face do Estado (HACHEM, 2011, p. 166). É o caso, por exemplo, dos princípios da impessoalidade e da publicidade. A identificação desses reflexos do princípio da indisponibilidade é bastante fácil.

12 Humberto Ávila, nesse sentido, que deve haver um "fundamento de validade no direito positivo, de modo expresso ou implícito," para que uma determinada disposição seja considerada como uma "norma-princípio". Cf. ÁVILA, Humberto. Repensando o "princípio da supremacia do interesse público sobre o particular". In: SARMENTO, Daniel (Org.). Interesses públicos versus interesses privados: desconstruindo o princípio da supremacia do interesse público. 3. tir. Rio de Janeiro: Lumen Juris, 2010. p. 181. 
O que pouco se fala, entretanto, é sobre quais são os fundamentos desse princípio. Isto é, para além daquilo que são considerados como frutos da indisponibilidade, o que de fato pode ser tomado como a base que sustenta a existência desse princípio no Direito brasileiro?

Na tentativa de se identificar uma resposta a essa pergunta, o primeiro e mais fácil caminho a ser perseguido é buscar no próprio texto constitucional alguma menção explícita ao princípio da indisponibilidade do interesse público. 0 esforço, entretanto, seria inócuo. Não há nenhum dispositivo constitucional que expressamente vincule a Administração Pública a um "princípio da indisponibilidade do interesse público" ou a qualquer outro com redação semelhante.

O fato, entretanto, de não haver dispositivo constitucional expresso nesse sentido de modo algum pode ser visto como um obstáculo definitivo à defesa da existência jurídica do princípio da indisponibilidade do interesse público no Direito brasileiro. Nessa linha, o administrativista espanhol Alejandro Nieto (1991, p. 2225) lembra que se - diferentemente do que ocorre em seu país - não existe previsão expressa de que a Administração deve seguir o interesse público em todas as Constituições, isso se deve simplesmente ao fato de que tal vinculação é uma conclusão óbvia.

É prudente recordar que na mesma situação do princípio da indisponibilidade do interesse público estão outros princípios constitucionais de extrema relevância como a segurança jurídica, a proporcionalidade e a razoabilidade - nenhum deles encontrado de modo explícito em um dispositivo constitucional. Apesar de tal situação, não se faz nenhum grande questionamento a respeito da existência de tais princípios, amplamente reconhecidos pela doutrina e aplicados pela jurisprudência nacional. A razão para isto é a de que tais normas podem facilmente ser deduzidas do texto constitucional. Idêntica, mais uma vez, é a situação do princípio da indisponibilidade, que, sendo extraível de um amplo conjunto de normas constitucionais, apresenta-se como um princípio constitucional implícito do Direito Administrativo brasileiro.

Nesse sentido, Mariana de Siqueira (2016, p. 195) concorda que, apesar de não ser "texto expresso nas disposições da Constituição de 1988, nem por isso, todavia, carece de proteção jurídica" o princípio da indisponibilidade do interesse público. Daniel Wunder Hachem (2011, p. 118), na mesma linha, chega a afirmar que "não há dúvidas que a indisponibilidade dos interesses públicos, como ideia-síntese das sujeições especiais da Administração Pública em prol do cidadão, pode ser identificada como um princípio implícito no tecido constitucional", sendo que o "dever da Administração de obedecer a todos os seus desdobramentos (...) resulta diretamente da sua submissão à Constituição".

O caminho, então, é buscar identificar no texto constitucional quais são os dispositivos que servem de base para justificar a existência do princípio da indisponibilidade do interesse público no Direito Administrativo brasileiro.

Logo no preâmbulo já se encontra a determinação (ainda que não de uma forma vinculativa, mas como uma importante orientação hermenêutica) de que o Estado brasileiro é instituído com o destino de assegurar o bem-estar da população (entre outros valores supremos como a liberdade, a igualdade e a justiça). ${ }^{13}$ Em sentido semelhante - e aí com força vincu- 
lante em face da atividade administrativa - propugna o art. $3^{\circ}$, IV que se tratam de objetivos fundamentais da República a promoção do "bem de todos, sem preconceitos de origem, raça, sexo, cor, idade e quaisquer outras formas de discriminação"..$^{14}$

Ora, como ensina Héctor Jorge Escola (1989, p. 31), na Argentina a persecução do interesse público é considerado um princípio constitucional exatamente por conta da expressão "bem-estar geral" no preâmbulo da Constituição, de modo muito semelhante como acontece no Brasil. Em âmbito nacional, Juarez Freitas (2009, p. 54) é um dos autores que adota posição semelhante ao afirmar, baseando no dispositivo constitucional citado acima, que "o princípio do interesse público prescreve que, em caso de colisão, deve preponderar a vontade geral legítima (o 'bem de todos' no dizer do art. $3^{\circ}$ da CF) sobre a vontade egoisticamente articulada ou facciosa".

Além dos dispositivos citados acima, uma interpretação sistemática das normas constitucionais também é capaz de demonstrar a fundamentação implícita do princípio da indisponibilidade no texto constitucional em outras normas de conteúdo semelhante ao preâmbulo e ao art. $3^{\circ}$, IV. Quando a Constituição, em diversos de seus artigos, parágrafos e incisos, prevê um dever do Estado de promover a justiça social, a solidariedade e a harmonia entre os cidadãos, percebe-se que ela está a vincular a atividade administrativa ao combate às desigualdades, à inclusão dos indivíduos marginalizados e à luta contra as opressões de toda espécie. Em resumo, há a "impossibilidade de se permitir a primazia de interesses exclusivamente particulares sobre bens jurídicos tutelados constitucionalmente" (HACHEM, 2011, p. 125).

Desse modo, o fato de o preâmbulo e de o art. $3^{\circ}$, IV, da Constituição (entre tantos outros que, de maneira menos direta, apontam para o mesmo sentido) determinarem a realização do bem-estar geral como um objetivo basilar da Administração Pública já seria justificativa normativa suficiente para se reconhecer a existência do princípio da indisponibilidade do interesse público no ordenamento jurídico brasileiro.

Há, entretanto, um dispositivo que vincula de maneira ainda mais consistente a atividade administrativa à plena e incessante concretização do interesse público. Trata-se do art. $1^{\circ}$ da Constituição Federal, que define o Estado brasileiro como uma República. ${ }^{15}$ Muito mais do que uma mera "abstrata declaração de intenções a figurar no texto constitucional", essa expressão se constitui como "um comando objetivo aplicável e exigível a toda aplicação do sistema normativo brasileiro, constitucional e infraconstitucional", sendo que "o princípio republicano, aliado à condição de Estado Democrático de Direito, é pois, impositivo a todas as relações entre o Estado e seu povo" (LIMA, 2013, p. 108-109).

Tradicionalmente, a República é enxergada como uma forma de governo que se opõe à Monarquia, por constituir um Estado no qual o poder público é exercido por representantes do povo, especificamente eleitos para essa função e com diversas limitações em sua atua-

individuais, a liberdade, a segurança, o bem-estar, o desenvolvimento, a igualdade e a justiça como valores supremos de uma sociedade fraterna, pluralista e sem preconceitos, fundada na harmonia social e comprometida, na ordem interna e internacional, com a solução pacífica das controvérsias, promulgamos, sob a proteção de Deus, a seguinte CONSTITUIÇÃO DA REPÚBLICA FEDERATIVA DO BRASIL.

14 Constituição da República Federativa do Brasil. Art. $3^{\circ}$. Constituem objetivos fundamentais da República Federativa do Brasil: IV - promover o bem de todos, sem preconceitos de origem, raça, sexo, cor, idade e quaisquer outras formas de discriminação.

15 Constituição da República Federativa do Brasil. Art. $1^{\circ}$. A República Federativa do Brasil, formada pela união indissolúvel dos Estados e Municípios e do Distrito Federal, constitui-se em Estado Democrático de Direito e tem como fundamentos. 
ção - e não por mandatários absolutistas levados ao poder por razões teológicas e hereditárias (DALLARI, 2012, p. 225-227). Tal diferenciação, entretanto, apesar de sua importância para fins didáticos e de seu valor histórico, não pode ser acatada integralmente na sociedade contemporânea, tendo em vista que a maioria das Monarquias no mundo hoje estão inseridas em regimes democráticos (BARCELLOS, 2018, p. 118).

Na busca de uma definição para o termo, Ana Paula de Barcellos (2018, p. 118-119) ressalta que, em que pese existirem inúmeras posições divergentes sobre o real significado do princípio republicano, o que faz ser impossível a tarefa de encontrar "um sentido histórico unívoco e simples", analisando todas essas concepções é possível "identificar uma ideia essencial comum: trata-se da noção, de alguma forma associada à ideia de república, de restrição do poder absoluto, de governo justo e do exercício do poder político orientado para o bem da coletividade". Em outro trecho, a constitucionalista reforça que a expressão "república" encontra-se "associada às noções de governo justo, de Estado de Direito, primazia do interesse público e, principalmente, controle do poder". A partir daí já é possível começar a se compreender a relação entre o republicanismo e o princípio da indisponibilidade do interesse público.

Em uma República, a atividade dos agentes públicos, enquanto representantes da sociedade e detentores de poderes públicos, deve se pautar por um critério de neutralidade (GABARDO, 2009, p. 363), sem se utilizar das prerrogativas disponibilizadas pela máquina administrativa para privilegiar ou prejudicar pessoas ou grupos sociais em específicos por razões pessoais. ${ }^{16} \mathrm{Na}$ ordem constitucional brasileira, esse valor foi positivado no art. 37 através do princípio da impessoalidade. Mas também é evidente sua relação intrínseca com a concepção de que a Administração deve agir em prol de interesses públicos - e não privados-, algo que reforça a tese de que a indisponibilidade do interesse público pela Administração é um princípio jurídico implícito extraível do modelo republicano de Estado expressamente adotado pela Constituição Federal de 1988.

Assim, é possível afirmar que a indisponibilidade do interesse público é um reflexo indiscutível do ideal de republicanismo que permeia a Constituição brasileira. A partir disso, o que se pode discutir são no máximo as consequências práticas do princípio da indisponibilidade, mas o fato de que a Administração Pública de uma República deve perseguir interesses públicos, que digam respeito a toda a coletividade e não apenas a determinados grupos de indivíduos que os detentores do poder quiser privilegiar, é indiscutível. Afinal, como ensina Emerson Gabardo (2009, p. 363), "uma república em que não se tome como ponto de partida que deve ser priorizado o interesse comum em face dos interesses de caráter particular certamente não será uma república verdadeira".

Outro dispositivo constitucional que também fundamenta a existência do princípio da indisponibilidade, ainda que de maneira mais discreta que os anteriores, é o art. $66, \S 1^{\circ}$, que prescreve que "se o Presidente da República considerar o projeto, no todo ou em parte, inconstitucional ou contrário ao interesse público, vetá-lo-á total ou parcialmente [...]".

A bem da verdade, nesse momento a Constituição parece estar se referindo a um conceito mais político de interesse público, principalmente porque coloca essa hipótese de veto

16 Nesse sentido, Ana Paula de Barcellos registra que "o ideal republicano impõe a separação entre interesses privados dos agentes públicos e o interesse público que lhes cabe defender ou promover". BARCELLOS, Ana Paula de. Curso de direito constitucional. Rio de Janeiro: Forense, 2018. p. 119. 
ao lado daquela em que o Presidente identifica alguma inconstitucionalidade no projeto legislativo. Ainda assim, tal dispositivo não deixa de servir como mais um indicativo do rumo que a Constituição pretende impor à Administração Pública. Dele se extrai que a vinculação da atividade estatal à realização do interesse público é tamanha que o Presidente da República está autorizado a vetar uma lei aprovada regularmente pelos representantes democráticos do povo, caso considere que a norma irá importar afronta ao interesse da coletividade.

O mesmo ocorre com o art. 57, $\S 6^{0},{ }^{17}$ com o art. 93, VIII, ${ }^{18}$ com o art. 95, II ${ }^{19}$ e com o art. $231, \S 6^{\circ}{ }^{20}$ São todos dispositivos constitucionais que servem de exemplo para comprovar a tese de que quando verificada a presença de um dado interesse público a Administração Pública está instada a agir de um determinado modo, através de atos que não poderia praticar caso tal prática não fosse estritamente necessária para a tutela do interesse público.

Embora não diretamente em âmbito constitucional, também é interessante trazer à baila nesse momento o art. $2^{\circ}$, "e)" e parágrafo único, "e)" da Lei no 4.171/65. ${ }^{21}$ Diz-se que apenas não diretamente constitucional, pois é bom lembrar que embora anterior à Constituição atualmente vigente, referida legislação possui, no presente cenário, a função de regulamentar o art. 50, LXXIII da Lei Maior. ${ }^{22}$ Pois bem. Tal dispositivo prevê a possibilidade de anulação, através do instrumento da Ação Popular, de atos administrativos editados com finalidade diversa daquela prescrita em lei para tal competência.

Principalmente antes das teorizações de Celso Antônio Bandeira de Mello a respeito da matéria, o dever da Administração de buscar a concretização do interesse público era veiculado pela doutrina não pelo princípio da "indisponibilidade do interesse público", mas normalmente como algo atrelado ao atributo da finalidade dos atos administrativos. Paradigmática nesse sentido é a lição de José Cretella Júnior (1966, p. 240) ao pontuar que "se o agente, levado por móveis outros que o interesse público, edita o ato administrativo, este leva um vício grave de origem, informado que foi por finalidade incompatível com aquela que impulsiona o pessoal do Estado".

Desse modo, se, à época, o atributo da finalidade dos atos administrativos era visto como elo principal que vinculava a Administração Pública à satisfação do interesse público,

17 Constituição da República Federativa do Brasil. Art. 57. §6 ${ }^{\circ}$ A convocação extraordinária do Congresso Nacional far-se-á: II - pelo Presidente da República, pelos Presidentes da Câmara dos Deputados e do Senado Federal ou a requerimento da maioria dos membros de ambas as Casas, em caso de urgência ou interesse público relevante, em todas as hipóteses deste inciso com a aprovação da maioria absoluta de cada uma das Casas do Congresso Nacional.

18 Constituição da República Federativa do Brasil. Art. 93. VIII - o ato de remoção, disponibilidade e aposentadoria do magistrado, por interesse público, fundar-se-á em decisão por voto da maioria absoluta do respectivo tribunal ou do Conselho Nacional de Justiça, assegurada ampla defesa.

19 Constituição da República Federativa do Brasil. Art. 95. Os juízes gozam das seguintes garantias: II - inamovibilidade, salvo por motivo de interesse público, na forma do art. 93, VII.

20 Constituição da República Federativa do Brasil. Art. 231. \$6 . São nulos e extintos, não produzindo efeitos jurídicos, os atos que tenham por objeto a ocupação, o domínio e a posse das terras a que se refere este artigo, ou a exploração das riquezas naturais do solo, dos rios e dos lagos nelas existentes, ressalvado relevante interesse público da União, segundo o que dispuser lei complementar, não gerando a nulidade e a extinção direito a indenização ou a ações contra a União, salvo, na forma da lei, quanto às benfeitorias derivadas da ocupação de boa fé.

21 Lei ${ }^{\circ} 4.171 / 65$. Art. $2^{\circ}$ São nulos os atos lesivos ao patrimônio das entidades mencionadas no artigo anterior, nos casos de: e) desvio de finalidade. Parágrafo único. Para a conceituação dos casos de nulidade observar-se-ão as seguintes normas: e) o desvio de finalidade se verifica quando o agente pratica o ato visando a fim diverso daquele previsto, explícita ou implicitamente, na regra de competência.

22 Constituição da República Federativa do Brasil. Art. $5^{\circ}$. LXXIII - qualquer cidadão é parte legítima para propor ação popular que vise a anular ato lesivo ao patrimônio público ou de entidade de que o Estado participe, à moralidade administrativa, ao meio ambiente e ao patrimônio histórico e cultural, ficando o autor, salvo comprovada má-fé, isento de custas judiciais e do ônus da sucumbência. 
é correto compreender que ao prescrever no art. $2^{\circ}$, "e)" da Lei de Ação Popular que serão nulos os atos em que se verificar algum tipo de desvio de finalidade, o legislador nesse momento reforçou a antijuridicidade de qualquer atuação da Administração Pública que se distanciasse do atendimento do interesse público.

Sendo assim, é visível a previsão de diversos dispositivos normativos no direito positivo brasileiro que justificam a existência do princípio da indisponibilidade do interesse público no Direito Administrativo pátrio.

\section{OS IMPACTOS DA INDISPONIBILIDADE DO INTERESSE PÚBLICO PARA O DIREITO ADMINISTRATIVO BRASILEIRO}

Acima viu-se os principais dispositivos normativos que fundamentam o princípio da indisponibilidade do interesse público no ordenamento jurídico pátrio. Das explicações tecidas sobre eles, percebe-se ser inquestionável a existência jurídica de tal norma no Direito Administrativo brasileiro. Deve-se agora, então, compreender quais os impactos que a indisponibilidade do interesse público, uma vez devidamente reconhecida como princípio jurídico, traz para o regime jurídico-administrativo.

De acordo com Celso Antônio Bandeira de Mello (2015, p. 77), as principais consequências jurídicas do princípio da indisponibilidade do interesse público são: (i) o princípio da legalidade e suas decorrências como a finalidade, a razoabilidade e a proporcionalidade, a motivação e a responsabilidade do Estado; (ii) a obrigatoriedade do desempenho da atividade pública/continuidade dos serviços públicos; (iii) o controle (interno e externo) dos atos administrativos; (iv) o tratamento isonômico dos cidadãos em face da Administração; (v) publicidade; (vi) inalienabilidade dos direitos concernentes a interesses públicos. Passa-se agora a analisar, pois, cada uma dessas características.

(i) Nas palavras de Bandeira de Mello (2015, p. 78), o princípio da legalidade administrativa é "uma decorrência natural da indisponibilidade do interesse público". Ora, uma vez que o interesse público está consagrado na legislação positiva, é lógico que do dever da Administração de promover este interesse público decorra o dever de respeitar a legislação, subordinando toda sua atividade às normas jurídicas consagradas no ordenamento. 0 mais interessante desse ponto, então, parece estar naquilo que Celso Antônio considera como as decorrências do princípio da indisponibilidade: (i.1) a finalidade; (i.2) a razoabilidade e a proporcionalidade; (i.3) a motivação e (i.4) a responsabilidade do Estado

(i.1) 0 atributo da finalidade dos atos administrativos, como já dito, está intimamente relacionado à noção de indisponibilidade do interesse público. É certo que "não se aplica uma lei corretamente se o ato de aplicação carecer de sintonia com o escopo por ela visado" (MELLO, 2015, p. 80). Assim, o dever de todos os atos jurídicos que correspondam a manifestações de vontade da Administração Pública sejam editados objetivando o cumprimento de determinada finalidade prevista em lei (e não qualquer finalidade que deseje, pessoal e subjetivamente, a autoridade pública) é uma decorrência do princípio da indisponibilidade. É 
esse elo que vincula a atividade administrativa, sob pena de invalidade jurídica, à permanente busca de realização do interesse público.

(i.2) Principalmente nos casos em que a Administração goza de certa margem de discricionariedade para identificar um dado interesse público e, assim, tomar a decisão que lhe compete, a indisponibilidade do interesse público exige que essa decisão seja razoável e proporcional em relação aos direitos e interesses que estão em jogo. Não se poderia considerar como de interesse público um ato administrativo que destoasse dos padrões jurídicos de razoabilidade ou que não fosse adequado, necessário e proporcional ao fim a que ele supostamente se destina.

(i.3) O dever de motivação dos atos administrativos não apenas é um requisito essencial para que a categoria jurídica do interesse público possa ser adequadamente aplicada em qualquer caso, como também se mostra como uma consequência do princípio da indisponibilidade. Ora, uma vez que os bens e direitos são públicos e não próprios do administrador, a autoridade deve demonstrar fundamentadamente todas as razões que a levaram a tomar determinada decisão. Apenas assim os cidadãos e os órgãos de controle poderão verificar se o ato administrativo realmente foi editado visando a consecução de uma finalidade pública ou se, por outro lado, ao fazê-lo a Administração destoou do seu dever de realização do interesse público.

(i.4) Apenas em relação ao regime de responsabilidade civil do Estado, ousa-se discordar de Bandeira de Mello, por não se vislumbrar tal característica como uma decorrência do princípio da indisponibilidade. Diferentemente do que se passa com os outros fatores analisados acima, a responsabilidade civil não é uma sujeição típica ou extraordinária do regime administrativo. Todas as pessoas, físicas ou jurídicas, públicas ou privadas, estão submetidas a algum sistema de responsabilização civil. Ainda que o regime da responsabilidade civil do Estado destoe daquele que, em regra, é aplicado aos particulares, ${ }^{23}$ isso não é capaz de justificar uma relação entre tal característica e o princípio da indisponibilidade.

Atualmente, a modalidade objetiva de responsabilização civil já vem sendo adotada também para particulares que se encontrarem inseridos em determinados contextos. Um exemplo patente disso são empresas privadas cuja atuação de algum modo impacte em temas afetos ao Direito Ambiental. Nesses casos, as empresas são objetivamente responsáveis pelos danos que causarem ao meio-ambiente. Assim, entende-se que a sujeição ao regime de responsabilização civil na modalidade objetiva é uma opção legislativa que decorre da situação de fato da atividade que determinado ente executar, não sendo algo próprio e exclusivo do regime jurídico-administrativo.

(ii) O dever de continuidade de execução das atividades administrativas é uma clara decorrência do princípio da indisponibilidade do interesse público, uma vez que, não sendo proprietário da coisa pública, não pode o administrador dar-se à possibilidade de deliberadamente deixar de cumprir determinada competência administrativa. ${ }^{24}$ Como já defendido em

23 Sobre o regime de responsabilização civil do Estado no Brasil, ver: FARIA, Luzardo. A ineficiência do atual modelo de responsabilização civil do Estado no Brasil e a necessidade de prevenção de danos. Revista Digital de Direito Administrativo, São Paulo, v. 4, n. 2, p. 117-136, jul. 2017. p. 118-119.

24 Nas palavras de Celso Antônio Bandeira de Mello, "uma vez que a administração é curadora de determinados interesses que a lei define como públicos e considerando que a defesa, e prosseguimento deles, é, para ela, obrigatória, verdadeiro dever, a continuidade da atividade administrativa é princípio que se impõe e prevalece em quaisquer circunstâncias". MELLO, Celso Antônio Bandeira de. Curso de Direito Administrativo. 32. ed. São Paulo: Malheiros, 2015. p. 84. 
outra oportunidade, "no momento que o Estado toma para si a titularidade da prestação de determinado serviço, parece lógico deduzir que dele se espera uma prestação contínua, sob pena de, não satisfazendo as necessidades presentes naquela situação, violar a dignidade dos cidadãos atingidos" (FARIA, 2015, p. 121). O comentário, desenvolvido tendo por base o âmbito dos serviços públicos, nos quais o princípio da continuidade é mais comumente estudado, aplica-se sem grandes diferenciações a qualquer outra atividade administrativa.

(iii) A submissão da atividade administrativa ao controle externo e interno é mais uma típica consequência jurídica do princípio da indisponibilidade do interesse público.

Sua relação com o princípio da indisponibilidade do interesse público é algo indissolúvel, pois apenas através do controle é que se poderá verificar se os atos editados pela Administração Pública de fato foram expedidos com vistas à realização do interesse público. O controle exerce importância ímpar para possibilitar o pleno atendimento ao princípio da indisponibilidade, pois sem ele outras decorrências desse postulado (como a legalidade, a finalidade e a motivação, por exemplo) seriam inócuas. É a possibilidade de controle que permite, através de diversas técnicas, a correção de atos administrativos que destoarem do cumprimento do interesse público, impondo coercitivamente à Administração a obrigação de executar apenas as decisões que derem efetividade a esse mandamento e descartar aquelas que dele se distanciarem.

(iv) O tratamento isonômico dos cidadãos em face da Administração e o princípio da impessoalidade administrativa, do qual é expressão direta, também possuem amparo na indisponibilidade do interesse público. Essa relação já foi ressaltada quando se demonstrou que o principal dispositivo jurídico que fundamenta no plano normativo a existência do princípio da indisponibilidade no Direito Administrativo pátrio é o art. $1^{\circ}$ da Constituição Federal, ao classificar o Estado brasileiro como sendo uma República. É que "sendo encarregada de gerir interesses de toda a coletividade, a Administração não tem sobre estes bens disponibilidade que the confira o direito de tratar desigualmente àqueles cujos interesses representa" (MELLO, 2015, p. 86). Com efeito, se o administrador é, segundo o princípio da indisponibilidade, mero gestor da res publica (FARIA, 2013, p. 69), obviamente não pode geri-la de modo a privilegiar ou prejudicar alguém por razões de índole pessoal.

(v) Por fim, a inalienabilidade dos direitos concernentes a interesses públicos é a última das decorrências do princípio da indisponibilidade do interesse público identificada por Celso Antônio Bandeira de Mello. A razão para isso, segundo o administrativista, é a de que "sendo a administração atividade serviente, desenvolvida em nível infralegal, não pode alienar ou ser despojada dos direitos que a lei consagrou como internos ao setor público" (MELLO, 2015, p. 88). De modo semelhante, Hely Lopes Meirelles (2012, p. 105) defende que a Administração "não pode renunciar a poderes que a lei lhe deu para tal tutela, mesmo porque ela não é titular do interesse público, cujo titular é o Estado".

A posição, entretanto, deve ser encarada com muita cautela. De fato, os bens e direitos da Administração Pública não estão à "livre" disposição do administrador. Ocorre, porém, que em determinadas situações o ordenamento jurídico poderá exigir - caso essa seja a melhor resposta que se ofereça para resolver o conflito verificado no caso concreto - que a Administração disponha de algum bem ou direito em específico. Novamente: isso não passa por uma apreciação livre e subjetiva dos desejos pessoais do administrador, mas sim pelos indicativos que forem extraíveis do corpo de normas jurídicas a que ele estiver vinculado. 
Verifica-se, assim, que muitas vezes a posição pré-formatada e estanque de indisponibilidade de bens e direitos titularizados pela Administração Pública poderá corresponder, em última análise, a uma violação ao princípio da indisponibilidade. Como destacado anteriormente, é comum que supostos interesses públicos gerais (devidamente garantidos pelo ordenamento jurídico) percam a sua real qualidade de interesse público em determinadas situações concretas, inclusive possibilitando o atendimento, nesse sentido, de interesses individuais ou coletivos stricto sensu. Ou seja, é perfeitamente possível que, diante de um contexto fático e jurídico específico, a Administração esteja autorizada a dispor de parcela de seus bens ou direitos, caso essa se mostre a opção que melhor atenderá ao interesse público identificado naquele caso concreto.

Esse é apenas um dos exemplos aptos a justificar que é chegado o momento de realizar uma releitura do princípio da indisponibilidade, a fim de "permitir, conforme a ordem jurídica e à luz das circunstâncias fáticas, a utilização de instrumentos consensuais para a densificação do conceito de interesse público, bem como para a solução de conflitos administrativos" (MORETTI, 2012, p. 465-466).

De um modo geral, todas essas consequências advindas da incidência do princípio da indisponibilidade do interesse público sobre o regime jurídico-administrativo são "mecanismos hábeis a compelir o administrador pública à satisfação dos interesses da coletividade, afastando comportamentos personalistas ou vinculados a manifestações de sua vontade própria, e direcionando-o à consecução do interesse público" (HACHEM, 2011, p. 49). Assim, sua principal função é a de retirar qualquer margem de livre atuação na atividade administrativa. Por óbvio que ficam preservados os espaços de discricionariedade, no entanto esses devem ser explorados pela Administração de uma forma condicionada à realização do interesse público. Isto é, "a Administração não pode desistir de agir para a satisfação dos interesses que lhe foram confiados, embora isso não a tolha de escolher, nos limites da própria lei e do Direito, como, quando e de que modo fazê-lo" (MOREIRA NETO, 2006, p. 90).

\section{CONCLUSÓES}

Não existe um consenso na doutrina brasileira a respeito do conteúdo do princípio da indisponibilidade do interesse público - e isso talvez exatamente por conta de que os escritos sobre o tema via de regra nunca o enfrentaram com a especificidade necessária para compreendê-lo adequadamente.

No presente artigo defendeu-se que o conteúdo jurídico do princípio da indisponibilidade representa o dever inafastável da Administração Pública de envidar absolutamente toda a sua atividade em prol da satisfação do interesse público juridicamente definido. Por força do princípio da indisponibilidade, não pode haver ato administrativo que se destine a realização de qualquer objetivo que não coincida com o interesse público. Se assim não o fizer, deverá ser decretado inválido.

O princípio da indisponibilidade do interesse público funciona como uma amarra à atividade administrativa. Trata-se da outra face da moeda composta pelo princípio da suprema- 
cia. É ele que justifica (teoricamente) as prerrogativas exorbitantes que a legislação confere à Administração Pública ao condicionar o seu manejo à satisfação do interesse público.

A indisponibilidade, portanto, muito mais do que simplesmente dizer o óbvio (como criticam alguns autores), possui importante função de direcionamento da atividade jurídico-administrativa. É a indisponibilidade do interesse público a reposta, existente no próprio regime jurídico-administrativo, para frear os excessos indesejáveis que a Administração poderia vir a cometer caso Ihe fossem outorgadas apenas prerrogativas.

Quanto à sua natureza jurídica, viu-se que de acordo com o critério de grau de fundamentalidade não há dúvidas que a indisponibilidade do interesse público se apresenta como princípio. Trata-se de norma central do Direito Administrativo, que, ao lado da supremacia, dá o tom de todo o regime jurídico-administrativo.

Já com base no critério da estrutura lógico-normativa, defendeu-se que a indisponibilidade do interesse público apresenta-se, nesse ponto de vista, como regra. Afinal, supor que a indisponibilidade do interesse público pudesse ser vista como um mandado de otimização poderia levar à conclusão de que, dependendo das situações fáticas e jurídicas do caso concreto, a Administração Pública poderia estar mais ou menos vinculada à realização do interesse pública. Admitir-se-ia, nesse sentido, que em alguns casos a Administração deliberadamente deixasse de atender ao interesse público, o que vai exatamente na contramão daquilo que se reputou como sendo o conteúdo jurídico da indisponibilidade.

Na sequência, demonstrou-se que a indisponibilidade do interesse público é norma que encontra fundamento no Direito positivo brasileiro. Não de modo expresso, mas, sim, implicitamente no texto constitucional, a partir de diversos dispositivos normativos que atrelam a atividade administrativa à consecução do interesse público. Também se viu que em sede infraconstitucional são diversos os dispositivos que vinculam a Administração Pública à realização do interesse público, havendo-se destacado, nesse ponto, a Lei n 4.171/65.

Ao final, identificou-se as principais implicações trazidas pelo princípio da indisponibilidade ao regime jurídico-administrativo, analisando-as uma a uma, especificadamente. Trata-se: (i) do princípio da legalidade e de suas decorrências como a finalidade, a razoabilidade e a proporcionalidade, a motivação e a responsabilidade do Estado; (ii) da obrigatoriedade do desempenho da atividade pública/continuidade dos serviços públicos; (iii) do controle (interno e externo) dos atos administrativos; (iv) do tratamento isonômico dos cidadãos em face da Administração; (v) da publicidade; e (vi) da inalienabilidade dos direitos concernentes a interesses público.

\section{REFERENCIAS}

ALEXY, Robert. Teoría de los derechos fundamentales. 2. ed. Madrid: Centro de Estudios Políticos y Constitucionales, 2012.

AMARAL, Diogo de Freitas. Curso de Direito Administrativo. v. II. Coimbra: Almedina, 2001.

ARAÚJO, Edmir Netto de. Curso de Direito Administrativo. 5. ed. São Paulo: Saraiva, 2010. 
ATALIBA, Geraldo. Mudança da Constituição. Revista de Direito Público, São Paulo, n. 86, p. 181- 186, abr./jun. 1988.

ÁVILA, Humberto. Repensando o "princípio da supremacia do interesse público sobre o particular". In: SARMENTO, Daniel (Org.). Interesses públicos versus interesses privados: desconstruindo o princípio da supremacia do interesse público. 3. tir. Rio de Janeiro: Lumen Juris, 2010.

BACELLAR FILHO, Romeu Felipe. Prefácio. In: HACHEM, Daniel Wunder. Princípio constitucional da supremacia do interesse público. Belo Horizonte: Fórum, 2011.

BARCELLOS, Ana Paula de. A eficácia jurídica dos princípios constitucionais: o princípio da dignidade da pessoa humana. 3. ed. rev. e atual. Rio de Janeiro: Renovar, 2011.

BARCELLOS, Ana Paula de. Curso de direito constitucional. Rio de Janeiro: Forense, 2018.

BINENBOJM, Gustavo. Uma teoria do direito administrativo: direitos fundamentais, democracia e constitucionalização. 3. ed. rev. e atual. Rio de Janeiro: Renovar, 2014.

BRASIL. Constituição da República Federativa do Brasil, de 05 de outubro de 1988. Disponível em: http://www. planalto.gov.br/ccivil_03/Constituicao/Constituicao.htm.

BRASIL. Lei nº 7.347, de 24 de julho de 1985. Disponível em: http://www.planalto.gov.br/ccivil_03/leis/L7347orig. htm.

BRASIL. Lei n 9.784, de 29 de janeiro de 1999. Disponível em: http://www.planalto.gov.br/ccivil_03/leis/l9784. htm.

CANOTILHO, J. J. Gomes; MOREIRA, Vital. Fundamentos da constituição. Coimbra: Coimbra Editora, 1991.

CRETELLA JÚNIOR, José. Tratado de Direito Administrativo: Teoria do ato administrativo. v. 2. Rio de Janeiro: Forense, 1966.

DALLARI, Dalmo de Abreu. Elementos de Teoria Geral do Estado. 31. ed. São Paulo: Saraiva, 2012.

DI PIETRO, Maria Sylvia Zanella. Direito Administrativo. 2. ed. São Paulo: Atlas, 1991.

DWORKIN, Ronald. Levando os direitos a sério. 3. ed. São Paulo: Martins Fontes, 2010.

ESCOLA, Héctor Jorge. El interés público: como fundamento del derecho administrativo. Buenos Aires: Depalma, 1989.

FARIA, José Eduardo. Direito e economia na democratização brasileira. São Paulo: Saraiva, 2013.

FARIA, Luzardo. A ineficiência do atual modelo de responsabilização civil do Estado no Brasil e a necessidade de prevenção de danos. Revista Digital de Direito Administrativo, São Paulo, v. 4, n. 2, p. 117-136, jul. 2017.

FARIA, Luzardo. Suspensão do fornecimento de serviço público essencial por inadimplemento do usuário: o interesse público entre eficiência e dignidade. In: BLANCHET, Luiz Alberto; HACHEM, Daniel Wunder; SANTANO, Ana Claudia (Coords.). Eficiência e Ética na Administração Pública. Curitiba: Íthala, 2015.

FREITAS, Juarez. O controle dos atos administrativos e os princípios fundamentais. 4. ed. São Paulo: Malheiros, 2009.

GABARDO, Emerson. Interesse público e subsidiariedade: o Estado e a sociedade civil para além do bem e do mal. Belo Horizonte: Fórum, 2009.

GASPARINI, Diógenes. Direito Administrativo. São Paulo: Saraiva, 1989.

HACHEM, Daniel Wunder. Princípio constitucional da supremacia do interesse público. Belo Horizonte: Fórum, 2011.

HAEBERLIN, Mártin. Uma teoria do interesse público: fundamentos do Estado Meritocrático de Direito. Porto Alegre: Livraria do Advogado, 2017.

LEAL, Rogério Gesta. Controle da administração pública no Brasil: anotações críticas. A\&C - Revista de Direito Administrativo e Constitucional, Belo Horizonte, ano 5, n. 20, p. 125-143, abr./jun. 2005. 
LIMA, Martonio Mon'Alverne Barreto. Comentários ao art. 1. In: CANOTILHO, J. J. Gomes; MENDES, Gilmar Ferreira; SARLET, Ingo Wolfgang; STRECK, Lenio L. (Coords.). Comentários à Constituição do Brasil. São Paulo: Saraiva/Almedina, 2013.

LIMA, Ruy Cirne. Princípios de Direito Administrativo. 7. ed. São Paulo: Malheiros, 2007.

MARTINS JÚNIOR, Wallace Paiva. Princípio do interesse público. In: DI PIETRO, Maria Sylvia Zanella; MARTINS JÚNIOR, Wallace Paiva. Tratado de direito administrativo: teoria geral e princípios do direito administrativo. vol. 1. São Paulo: Revista dos Tribunais, 2014.

MEILAN GIL, José Luis. Intereses generales e interés público desde la perspectiva del derecho público español. In: BACELLAR FILHO, Romeu Felipe; HACHEM, Daniel Wunder (Coords.). Direito Administrativo e interesse público: estudos em homenagem ao Professor Celso Antônio Bandeira de Mello. Belo Horizonte: Fórum, 2010.

MEIRELLES, Hely Lopes. Direito Administrativo Brasileiro. 38. ed. São Paulo: Malheiros, 2012.

MELLO, Celso Antônio Bandeira de. Curso de Direito Administrativo. 32. ed. São Paulo: Malheiros, 2015.

MOREIRA NETO, Diogo de Figueiredo. Curso de Direito Administrativo. 14. ed. rev., ampl. e atual. Rio de Janeiro, 2006

MORENA, Luis de la Morena y de la. Derecho Administrativo e interés público: correlaciones básicas. Revista de Administración Pública, Madrid, n. 100-102, p. 847-880, ene./dic. 1983.

MORETTI, Natalia Pasquini. Uma concepção contemporânea do princípio da indisponibilidade do interesse público. In: MARRARA, Thiago (Org.). Princípios de direito administrativo: legalidade, segurança jurídica, impessoalidade, publicidade, motivação, eficiência, moralidade, razoabilidade, interesse público. São Paulo: Atlas, 2012.

NIETO, Alejandro. La administración sirve con objetividad los intereses generales. In: BAQUER, Sebastián Martin-Retortillo (Coord.). Estudios sobre la Constitución española: Homenaje al profesor Eduardo García de Enterría. v. 3. Madrid: Civitas, 1991.

ROCHA, Cármen Lúcia Antunes. Princípios constitucionais da Administração Pública. Belo Horizonte: Del Rey, 1994

SILVA, José Afonso da. Curso de Direito Constitucional Positivo. 32. ed. São Paulo: Malheiros, 2009.

SILVA, Virgílio Afonso da. Princípios e regras: mitos e equívocos acerca de uma distinção. Revista Latino-Americana de Estudos Constitucionais, Belo Horizonte, n. 1, p. 607-630, jan./jun. 2003.

SIQUEIRA, Mariana de. Interesse público no direito administrativo brasileiro: da construção da moldura à composição da pintura. Rio de Janeiro: Lumen Juris, 2016.

TAVEIRA NETO, Francisco. A evolução da Administração Pública e de seus mecanismos de controle na Constituição Federal. A\&C - Revista de Direito Administrativo e Constitucional, Belo Horizonte, ano 6, n. 23, p. 135-144, jan./mar. 2006.

\section{Recebido/Received: 20.11.2019}

Aprovado/Approved: 25.05.2020 